\title{
Phyto-therapeutic potential of stem bark of the wonder tree, Prosopis cineraria (L.) Druce in LPS-induced mouse model: An Anti-Inflammatory Study
}

\author{
Veena Sharma* and Preeti Sharma
}

\begin{abstract}
Background: Therapeutic potential of Prosopis cineraria has been extensively explored by many eminent researchers against various serious diseases but its activity against Lipopolysaccharide (endotoxin) is obscure. Therefore, present experimental investigation was conducted to unravel and analyze the anti-inflammatory potential of hydro-ethanol extract of Prosopis cineraria against LPS-induced inflammation in Swiss albino male mice.

Methods: Swiss Albino male mice were intoxicated (intra-peritoneal) with LPS ( $2 \mathrm{mg} / \mathrm{kg}$ body weight) and further treated with low and high dose (i.e. $100 \mathrm{mg} / \mathrm{kg}$ body weight and $300 \mathrm{mg} / \mathrm{kg}$ body weight respectively) of hydroethanol extract of stem-bark of Prosopis cineraria. The levels of cytokines (TNF-a, Prostaglandins E2, IL-6, NF-kBp65, IFN- $\gamma$ and IL-10) were determined in liver homogenate. Nitric oxide generated due to LPS-induced toxicity was estimated by using Griess reagent.
\end{abstract}

Results: The results demonstrated that the plant extract suppressed the over-expression and altered levels of cytokines

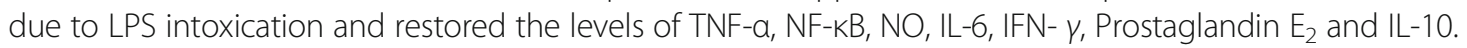

Conclusion: The present research work unravelled the alleviating potential of Prosopis cineraria against LPS-induced inflammation by modulating the expression of cytokines.

Keywords: Antioxidants, Anti-inflammatory, Prosopis cineraria, Oxidative stress, Reactive oxygen species, Cytokines

\section{Background}

Lipopolysaccharides (LPS), also referred as endotoxins, present in the outer monolayer of most gram negative bacteria is known to trigger innate immune response and inflammatory cascade in the host. Excessive and prolonged inflammatory response triggered by LPS in the host can lead to vascular leakage, septic shock or endotoxin shock, tissue and organ damage and can eventually cause death [1]. LPS has been extensively investigated and has potentially attracted the curiosity of

\footnotetext{
* Correspondence: drvshs@gmail.com

Department of Bioscience \& Biotechnology, Banasthali Vidyapith, Banasthali,
} Rajasthan, India

\section{Springer Open}

researchers because of their pathogenic role in numerous human and animal diseases [2].

The intensity of the response elicited by LPS depends on its dose and varies from species to species. Higher animals, humans are more sensitive even at low doses of LPS on the contrary; lower animals are quite resistant to LPS-induced deleterious effects [3]. Studies indicate the massive generation of reactive oxygen species (ROS) in LPS-induced signalling cascade [4]. ROS are known to have biocidal effects on invading micro-organisms and are important components of innate immune response. ROS include super-oxide anion radical, singlet oxygen, hydrogen peroxide and highly reactive hydroxyl radical. However, generation of ROS can potentially harm the tissues and organs of the host $[5,6]$. The lethal effects of (c) The Author(s). 2020 Open Access This article is licensed under a Creative Commons Attribution 4.0 International License, which permits use, sharing, adaptation, distribution and reproduction in any medium or format, as long as you give appropriate credit to the original author(s) and the source, provide a link to the Creative Commons licence, and indicate if changes were made. The images or other third party material in this article are included in the article's Creative Commons licence, unless indicated otherwise in a credit line to the material. If material is not included in the article's Creative Commons licence and your intended use is not permitted by statutory regulation or exceeds the permitted use, you will need to obtain permission directly from the copyright holder. To view a copy of this licence, visit http://creativecommons.org/licenses/by/4.0/. 
LPS are known to be elicited through activation of macrophages, neutrophils which consequently mediate the generation of pro-inflammatory cytokines and other bioactive inflammatory mediators including Tumour Necrosis Factor $\alpha$ (TNF- $\alpha$ ), Inetrleukin-6 (IL-6) and Nitric oxide (NO). LPS exerts stimulation of B-cell proliferation, production of antibody and activating $\mathrm{T}$ lymphocytes to produce cytokines [2].

Most common therapeutic treatment for bacterial infections is the administration of antibiotics. But ironically, the use of antibiotics for curing gram negative bacterial infections can increase endotoxin load and exaggerated inflammatory response. This is due to the fact that antibiotics kill the bacteria but the cell components mainly LPS, continue to elicit inflammatory response in the host [7]. Thus, in order to develop therapy or effective new drugs for sepsis, the detailed understanding of triggering of inflammatory response and mechanisms underlying the clinical manifestation of serious diseases in the host is indispensable.. Inflammatory disorders may cause abnormal inflammation that results in swelling, chronic pain,, redness stiffness, and tissue injury [8]. The inflammatory disorders include Rheumatoid arthritis, Gout, Asthma, Bronchitis, Periodontitis. The primary reciprocal action of the host to any harmful infection and injury is mostly an acute inflammation and can be effectively resolved by the downregulation of proinflammatory mediators and elimination of inflammatory cells at the sites of inflammation [9].

Numerous studies have been conducted to cure LPSinduced deleterious effects by using various plant extracts and compounds derived or isolated from plants. Stevioside, a glycoside from Stevia rabaudiana, has shown antiinflammatory activity in mice treated with LPS [10]. Green tea extracts have been shown to ameliorate LPS-induced thermal and hyperalgesia in mice by inhibiting COX-2 enzymes [11]. Salidroside, a glycoside component of medicinal plant Rhodiola rosea, exhibited anti-inflammatory activity by suppressing the expression of cytokines in microglial cells [12]. Reports were published this year on the study to investigate the effect of Ganoderma lucidum against LPS-induced liver injury. The results revealed a novel role in inhibition of inflammatory diseases by lowering the production of TNF- $\alpha$ and IL-6 [13].

Prosopis cineraria (L.) Druce, commonly referred as 'khejri', is the state tree of Rajasthan [14]. Prosopis cineraria has therapeutic importance and it is used for curing serious diseases and possess pharmacological activities like anti-fungal, anthelmintic, anti-cancer, anti-bacterial, anti-viral, anti-hyperglycemic, anti-hyperlipidemic, antioxidative [15]. Bark of $P$. cineraria is used in alleviation of various ailments such as asthma, leprosy, wandering of mind, fever, dyspepsia, dysentery, rheumatism, muscle tremors, bronchitis, piles, leucoderma [16, 17].
Even though elaborative research studies related to restorative and therapeutic potential of Prosopis cineraria against various toxicants have been carried out by eminent researchers but its activity against LPS-induced toxicity is still obscure. Considering the multiple uses of Prosopis cineraria for various medicinal purposes, there is a scope of investigating the curative effects of this plant against LPS-induced deleterious effects.

\section{Materials and methods Chemicals and ELISA kits}

Griess Reagent (Catalog\# G4410) and Lipopolysaccharide (from Escherichia coli 0111:B4) were procured from Sigma-aldrich. The chemicals and all the reagents mentioned in the present experimental research were of high purity (98-99\%) and analytical grade. Chemicals were purchased from reliable firms and sources. The ELISA kits were procured from Invitrogen by Life technologies, Invitrogen Corporation. TNF- $\alpha$ ELISA Kit (Catalog\#KMC3011); Prostaglandin $E_{2}$ ELISA Kit (Catalog\#KHL1701); IFN- $\gamma$ ELISA Kit (Catalog\#KMC4021); IL-6 ELISA Kit (Catalog\# KMC0061); IL-10 ELISA Kit (Catalog\# BMS614INST); NF-kBp65(Total) ELISA Kit (Catalog\#KHO0371).

\section{Experimental plant}

The stem-bark of Prosopis cineraria was procured from the local region of Banasthali Vidyapith, Rajasthan. The collected plant was identified by Farm Manager at Krishi Vigyan Kendra, Banasthali Vidyapith, Rajasthan and authenticated at Herbarium unit of Banasthali Vidyapith, Rajasthan, India (Herbarium No.-BVRI1359/2017).

\section{Preparation of plant extract}

The plant material i.e. stem bark was shade dried and then powdered by using mixer grinder. The powdered stem-bark $(30 \mathrm{~g})$ was packed in a thimble and subjected to sequential soxhlet extraction with Pet ether, Chloroform, Ethylacetate and Ethanol. After, the sequential extraction the marc obtained was extracted in water by maceration method.

\section{Preparation of hydro-ethanol extract-}

The powdered plant material was extracted with Pet ether and then the obtained marc was subjected to soxhlet extraction by $80 \%$ ethanol.

The extracts were evaporated to dryness using rotary evaporator and stored in air tight jars at $4{ }^{\circ} \mathrm{C}$ for further experimental usage. For experimental use, mixed the plant extracts with their respective solvents to achieve a concentration of $1 \mathrm{mg} / \mathrm{ml}$. 
Preliminary screening of phytochemicals and anti-oxidative potential of the plant extracts-

The phytochemical investigation and quantification studies for the presence of flavonoids, saponins, tannins, proanthocynidins, phenols were carried out. The antioxidative potential (DPPH assay) and free radical scavenging assays (Hydroxyl radical, Superoxide anion, Nitric oxide radical) were conducted so as to select the most potent and effective plant extract for further in-vivo experiments.

Based on the in-vitro studies, hydroethanol extract was recorded to possess potent anti-oxidative activity followed by Ethanol extract, Aqueous extract, Chloroform, Ethyl-acetate and Pet ether extract.

\section{Experimental animals}

The experimental animal model i.e. male Swiss Albino mice (Mus musculus) weighing between 15 and $30 \mathrm{~g}$ were procured from Lala Lajpat Rai University, Hissar (India). (Ref.No. BU/BT/402/14-15).

\section{Maintenance of animal models}

Swiss Albino adult male mice (Mus musculus) were maintained in a duly-ventilated animal house with $12 \mathrm{~h}$ light-dark cycle. Swiss albino mice were housed (six mice per cage) in polypropylene cages in an airconditioned room with ambient temperature (25 \pm $\left.30{ }^{\circ} \mathrm{C}\right)$, humidity $(50 \pm 15 \%)$. Proper hygienic and sterile conditions were maintained in the animal house facility. The mice were fed with a healthy pelleted diet (procured from Hindustan Lever Limited, India). The fed diet provided to experimental animal models constituted:- $\mathrm{Cu}$ 10.0, Mn- 55.0,, Zn- 45.0, Co- 5.0 and Fe- 75.0 [metal content in parts per million (ppm) dry weight] and drinking water ad libitum.

\section{Study design and treatment protocol}

In the present experimental study, 30 Swiss albino male mice were randomly selected (weighing approximately 20-30 g) and divided into five groups having six mice each. Group A was considered as control having six normal and healthy mice and received normal saline only.
Group B was considered as LPS treated group, 24 male mice were administered with LPS $(2 \mathrm{mg} / \mathrm{kg}$ of body weight, intraperitoneal dose) for 14 days. After 14 days the plant extract low dose, high dose and standard dose were administered to the animals from 15th day and continued to another 7 days. Therefore, the total duration of the treatment protocol was of 21 days. The groups are mentioned in the Table 1 given below:

\section{Preparation of liver homogenate}

After complete treatment to experimental animals, they were fasted overnight and then sacrificed by cervical dislocation. Liver tissues were removed and rinsed for cleaning in cold saline. After cleaning they were blotted dry then weight was taken. $10 \%(\mathrm{w} / \mathrm{v})$ liver tissue homogenate of each group was prepared by using $0.1 \mathrm{M}$ sodium phosphate buffer ( $\mathrm{pH} 7.0$ ). Weighed liver tissue samples of animals were homogenized in buffer using mortar and pestle and then centrifuged (at $9000 \mathrm{rpm}$ ) for the removal of cell debris. During the preparation of liver homogenate temperature was maintained at $4{ }^{\circ} \mathrm{C}$.

\section{Determination of cytokine levels in liver homogenate-}

The procedures and directions mentioned in the manuals provided along with the ELISA Kits for estimation of cytokines (TNF- $\alpha$, IL-10, IFN- $\gamma$, Prostaglandin $E_{2}$, IL6 and NF-kBp65) in liver tissue homogenates were followed.

\section{Determination of nitric oxide-}

Greiss Reagent was used to determine the levels of nitric oxide in the tissue samples by following the protocol previously reported [18].

\section{Calculation of cytokine levels-}

The absorbance was recorded and data was prepared prior to graphing. The average of the readings of triplicate wells was calculated. The standard curve was plotted to calculate the concentration of the samples by using the formula suggested by the kit.

Table 1 Representation of groups of experimental animals and the treatment to which were subjected

\begin{tabular}{|c|c|c|}
\hline \multicolumn{2}{|l|}{ Groups } & \multirow{2}{*}{$\begin{array}{l}\text { Treatments } \\
\text { Normal Saline }\end{array}$} \\
\hline Group A & Control $(n=6)$ & \\
\hline Group B & LPS Treated $(n=6)$ & $2 \mathrm{mg} / \mathrm{kg}$ body weight \\
\hline 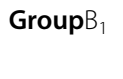 & $\begin{array}{l}\text { LPS }+ \text { Prosopis cineraria Low dose }(n= \\
6)\end{array}$ & $\begin{array}{l}\text { LPS ( } 2 \mathrm{mg} / \mathrm{kg} \text { body weight) }+ \text { Hydroethanol extract of Prosopis cineraria Low dose- } 100 \mathrm{mg} / \mathrm{kg} \\
\text { body weight }\end{array}$ \\
\hline Group $B_{2}$ & $\begin{array}{l}\text { LPS }+ \text { Prosopis cineraria high dose }(n= \\
6)\end{array}$ & $\begin{array}{l}\text { LPS }(2 \mathrm{mg} / \mathrm{kg} \text { body weight })+\text { Hydroethanol extract of Prosopis cineraria High dose- } 300 \mathrm{mg} / \mathrm{kg} \\
\text { body weight }\end{array}$ \\
\hline $\begin{array}{l}\text { Group } \\
B_{3}\end{array}$ & $\begin{array}{l}\text { LPS+ Standard (Dexamethasone) }(n= \\
6)\end{array}$ & LPS (2 mg/kg body weight) + Dexamethasone- $10 \mathrm{mg} / \mathrm{kg}$ body weight \\
\hline
\end{tabular}




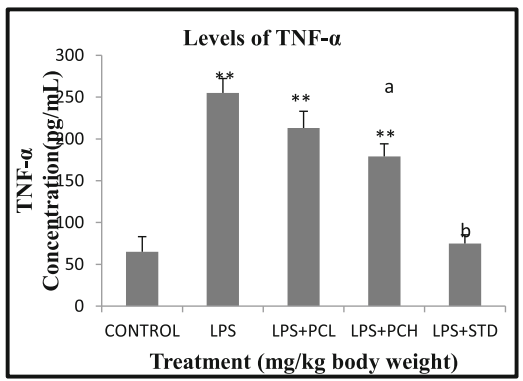

(A)

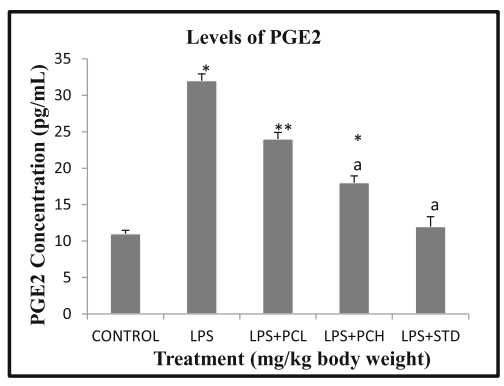

(B)

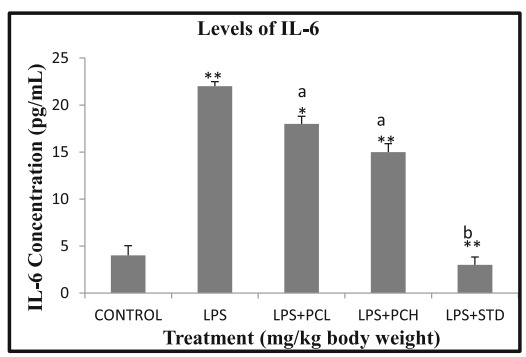

(C)

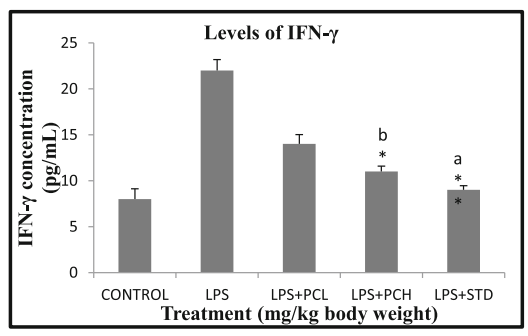

(D)

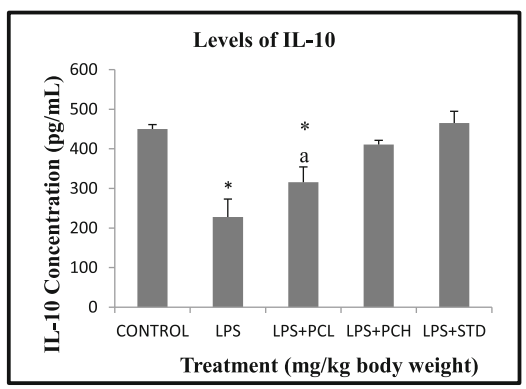

(E)
Fig. 1 Graphical Representation of levels of Cytokines: (a) TNF-a, (b) $\mathrm{PGE}_{2}$ (c) IL-6, (d) IFN- $\gamma$ and (e) IL-10 in Liver tissues of male Swiss albino mice. STD-Standard dose; PCL-Prosopis cineraria low dose; $\mathrm{PCH}$ - Prosopis cineraria high dose. Values are represented as mean \pm SD $(n=6) .{ }^{*} p<0.05,{ }^{* *} p<0.001 \mathrm{~V} / \mathrm{s}$ control group (C); ap $<0.05, b p<$ $0.001 \mathrm{~V} / \mathrm{s}$ LPS treated group

$\% \mathrm{~B} / \mathrm{BO}=($ Absorbance-Average NSB $) /$ Corrected $\mathrm{B} 0 * 100$

Formula to calculate corrected $\mathrm{B}_{0^{-}}$

$$
\text { Corrected B0 }=\text { Average B0 }- \text { Average NSB }
$$

Where, NSB- Non-specific Binding

$\mathrm{B}_{0}$ - Maximum Binding

The dilutions made to the samples prior to addition to the well were accounted. Thus, the calculated results were given in picogram units per milliliter $(\mathrm{pg} / \mathrm{ml})$.

\section{Statistical analysis-}

The results of the experiments were interpreted as mean \pm standard deviation of triplicates. The experimental data obtained was analyzed by one way ANOVA (analysis of variance) followed by student's t-test and tukey range test using the SPSS 16.0 (Statistical Program for Social Sciences) program. The experimental results with $p<0.05$ were considered as satisfactory and $p<$ 0.001 were considered as highly significant.

\section{Results}

To elucidate the anti-inflammatory potential of Prosopis cineraria, the activation of key cytokines TNF- $\alpha$, Prostaglandin $E_{2}$, IL-6, IL-10 and IFN- $\gamma$ were analyzed. In the results it was observed that LPS caused elevation in the levels of TNF- $\alpha$ (Fig. 1a), Prostaglandin $E_{2}$ (Fig. 1b), IL-6 (Fig. 1c) and IFN- $\gamma$ (Fig. 1d) in LPS-intoxicated group in comparison to untreated group (control). On the contrary, the levels of IL-10 (Fig. 1e) were reduced in LPStreated mice in contrast to untreated mice. Quantitative measurements revealed that low dose $(100 \mathrm{mg} / \mathrm{kg}$ body weight) and high dose (300 mg/ $\mathrm{kg}$ body weight) of Prosopis cineraria effectively restored the LPS-induced altered levels of the cytokines. Dexamethasone was also capable in alleviating and suppressing the levels of cytokines.

The research study undertaken aimed to detect and quantify the levels of NF-kBp65 protein, independent of its phosphorylation state. NF- $\mathrm{KB}$ is reported as a mediator of inflammatory responses, cell division and regulation of apoptosis. Results unravelled the elevated levels of NF- $\mathrm{KB}$ in LPS-intoxicated group in contrast to control group (Fig. 2). The elevated levels of the protein were lowered down by the action of low and high dose of plant extract. The standard drug (Dexamethasone) also suppressed the elevated levels of NF- $\mathrm{kB}$. 
The levels of Nitric oxide generated in the liver tissue samples were estimated in the research investigation. The results demonstrated that the levels of nitric oxide were highly enhanced in LPS-intoxicated group in contrast to control group (Fig. 3). The altered levels were restored by plant extract (low and high dose i.e. $100 \mathrm{mg} / \mathrm{kg}$ body weight and $300 \mathrm{mg} / \mathrm{kg}$ body weight) and standard drug (dexamethasone).

\section{Discussion}

The experimental outcomes of the present investigation revealed that the post treatment of the medicinal plant rendered ameliorative effects on LPS-induced mice model. Exposure to LPS is known to trigger a systemic inflammatory response (inflammatory cascade) in the host however, excessive inflammatory response can lead to vascular leakage, septic shock or endotoxin shock, tissue and organ damage and can eventually cause death [19-21]. When LPS binds to TLR-4, after binding NF$\kappa \mathrm{B}$, a transcription factor, gets activated and this leads to its translocation to nucleus and generation of many proinflammatory cytokines [22, 23]. LBP binds to circulating LPS and this binding of LPS-LBP to CD-14 stimulates monocytes to release TNF- $\alpha$ and pro-inflammatory cytokines (IL-6, IL-1, IL-10) (Fig. 4) [25]. Excessive secretion of these inflammatory mediators and cytokines is a major cause of tissue and organ damage [26]. Limited production of cytokines and inflammatory mediators are beneficial in stimulating the host immune system in order to fight against invading micro-organisms. TNF- $\alpha$ and IL-6 intensify the host immune response by stimulating receptor-carrying cells [25]. Furthermore, activated monocytes and macrophages release prostaglandins, ROS and

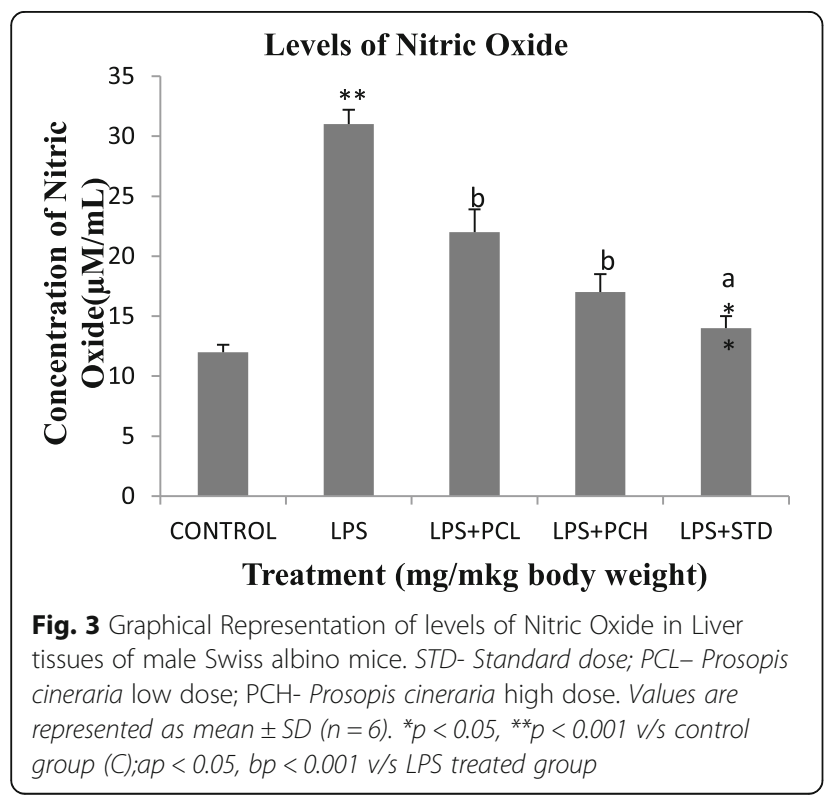

various other inflammatory cytokines subsequently resulting in organ damage [27].

Studies revealed that increase in oxidative stress is linked with activation of NF-kB. Exposure to hydrogen peroxide leads to the nuclear transfer of NF- $\mathrm{kB}$ and generation of various pro-inflammatory cytokines which can be curbed by the activity of anti-oxidants [28].

Prosopis cineraria showed considerable antiinflammatory effect against LPS induced inflammation in mice. Results unravelled that the levels of NF- $\mathrm{kB}$ were significantly higher in LPS-treated group A and there was a associated increment in the levels of inflammatory mediators such as IL-6, IFN- $\gamma$ and TNF- $\alpha$. The levels of $\mathrm{NF}-\mathrm{\kappa B}$ were reduced in the plant extract treated groups B1, B2 (low and high dose). The levels of other cytokines such as IL-6, IFN- $\gamma$ and TNF- $\alpha$ also lowered down. These observations are in the agreement with the previously published reports [29]. Increased levels of TNF- $\alpha$ cause elevation in the generation of reactive oxygen species (ROS) during inflammation [30].

Prosopis cineraria is a store house of various phytoconstituents like tannins, steroids, flavone derivatives (namely Prosogerin A, B, C and E), Rutin, Patulitrin, Luteolin, Patuletin, alkaloids etc. which possess antioxidative and anti-inflammatory potential. These antioxidants inhibit the nuclear translocation of NF- $\mathrm{KB}$, which subsequently trigger excessive production of cytokines and inflammatory mediators (Fig. 5).

IL 10 acts as a potent anti-inflammatory reagent by inhibiting the cytokine synthesis. The levels of IL-10 were depreciated in LPS-intoxicated group in contrast to control group. Il-10 levels were restored in plant extract treated groups. The anti-inflammatory activity of cytokine, IL-10, is attributed to its ability to reduce ROS levels [31].

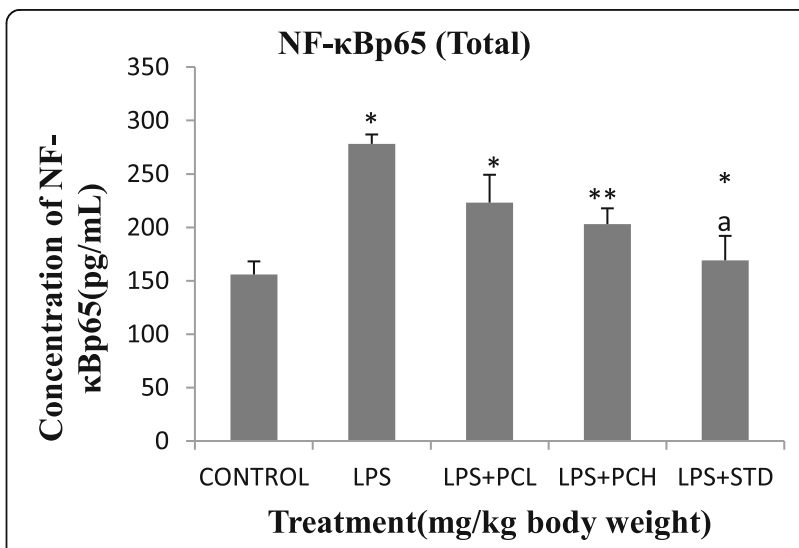

Fig. 2 Graphical Representation of levels of NF-KBp65 (Total) in Liver tissues of male Swiss albino mice. STD-Standard dose; PCL- Prosopis cineraria low dose; $\mathrm{PCH}$ - Prosopis cineraria high dose. Values are represented as mean $\pm S D(n=6) .{ }^{*} p<0.05,{ }^{* *} p<0.001 \mathrm{~V} / \mathrm{s}$ control group (C); $a p<0.05, b p<0.001 \mathrm{~V} / \mathrm{s}$ LPS treated group 


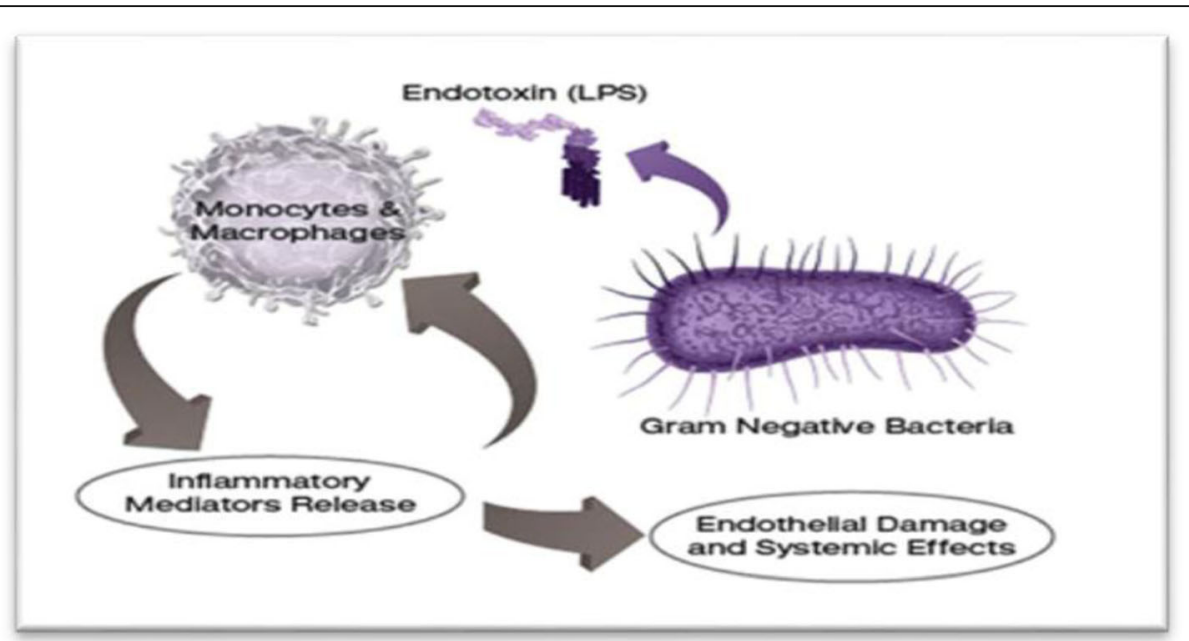

Fig. 4 Showing the effects of LPS on macrophages and release of Inflammatory mediators. (Endotoxin and Sepsis, Spectral medical) [24]

Prostaglandin $E_{2}$ levels were observed to be restored by the phyto-therapeutic treatment of plant extract (both low and high doses) on the contrary LPS-treated group showed marked elevation in $\mathrm{PGE}_{2}$ levels in comparison to control group. Research studies reveal that the antioxidants possess the capacity to curb the activity of COX-2 enzymes [32]. Prostaglandin $\mathrm{E}_{2}$ are produced by COX-2 enzyme activity therefore, inhibition of COX-2 enzymes cause decreases in generation of $\mathrm{PGE}_{2}$.

After several hours of LPS exposure nitric oxide is produced by macrophages on the contrary it is diffused within minutes by endothelial cells. Nitric oxide is a well

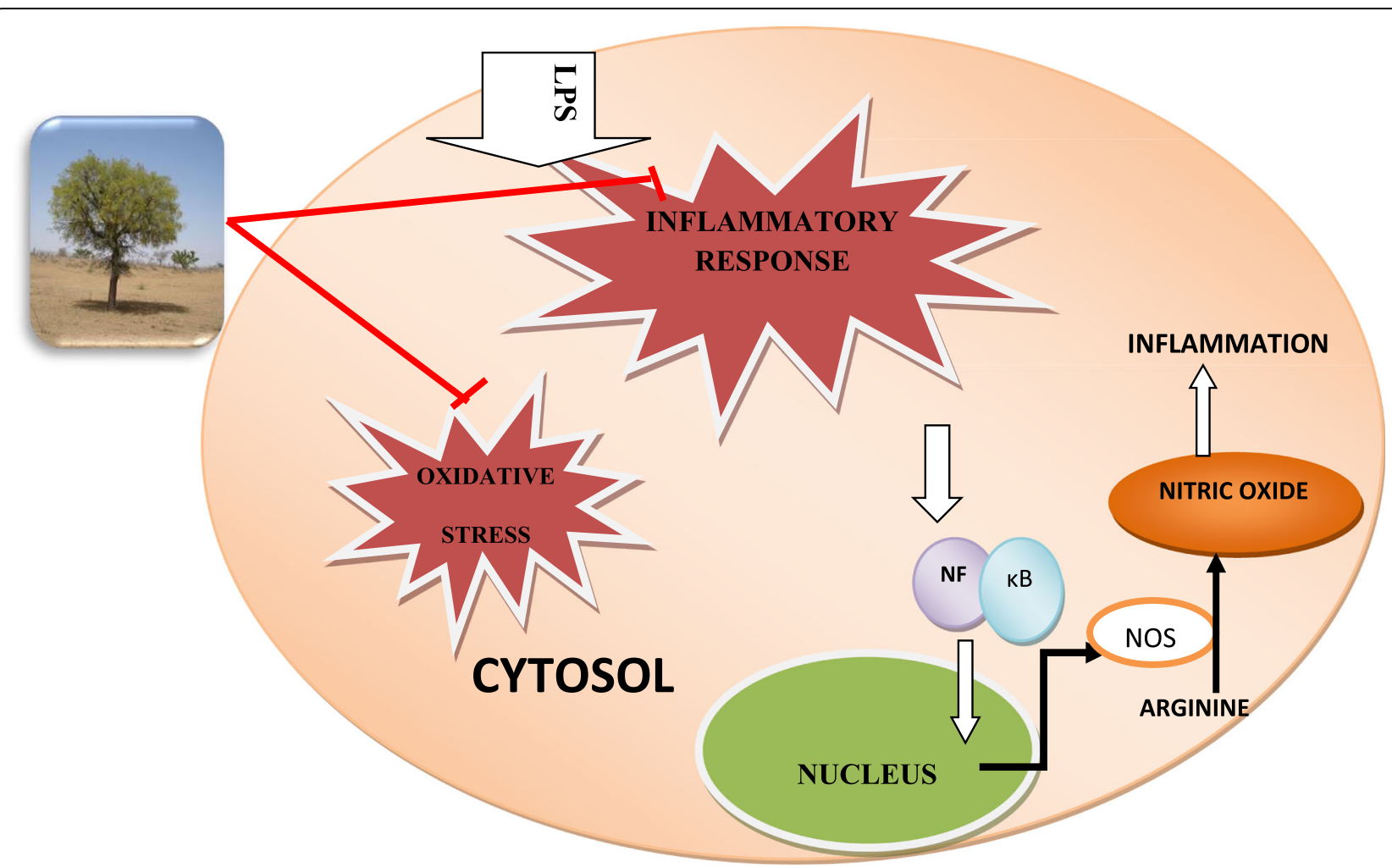

Fig. 5 Diagrammatic Representation of action of Prosopis cineraria against LPS-induced inflammation (imaged by Veena Sharma and Preeti Sharma) 
known vasodilator and its excessive generation can lead to hypotension [33]. The levels of Nitric oxide were higher in LPS-intoxicated group in contrast to control group. The plant extract ameliorated the altered levels of nitric oxide caused due to LPS-intoxication. Several studies have revealed that the antioxidants can downregulate the production of nitric oxide by inhibiting NF- $\mathrm{kB}$ activation [24]. The ability to restore the altered levels of nitric oxide is rendered upon Prosopis cineraria due to its potent anti-oxidative potential.

\section{Conclusion}

The present research investigation unravelled the alleviating potential of hydro-ethanol (80\%) stem-bark extract of Prosopis cineraria against LPS-induced toxicity by modulating the expression of cytokines. The bark extract of Prosopis cineraria possess rich quantity of polyphenols, flavonoids, tannins which possess anti-oxidative and anti-inflammatory potential. These antioxidants inhibit the transfer of NF- $\mathrm{kB}$ to nucleus, thereby inhibiting the exaggerated production of inflammatory mediators and thus, rendering curative role against LPS-induced cell damage. The extract can be used in future for isolation of active phytochemicals and in the formulation of effective medicinal drug against LPS-induced toxicity.

\section{Abbreviations \\ LPS: Lipopolysaccharide; TNF-a: Tumour Necrosis Factor-a; \\ $\mathrm{PGE}_{2}$ : Prostaglandins $\mathrm{E}_{2}$; IL-6: Interleukin-6; NF-KB: Nuclear Factor-KB; IFN- Y: Interferon-ү; IL-10: Interleukin-10; ROS: Reactive Oxygen Species; NO: Nitric Oxide; COX-2: Cyclooxygenase-2; ELISA: Enzyme-Linked Immuno-sorbent Assay; TLR-4: Toll-like Receptor-4; CD-14: Cluster of Differentiation-14; LBP: Lipopolysaccharide-Binding Protein}

\section{Acknowledgements}

The authors are immensely grateful and wish to acknowledge the support granted from Banasthali Vidyapith, Rajasthan for conducting experimental research work.

\section{Authors' contributions}

Author: Dr. Veena Sharma (Corresponding Author). Contributions: Supervisor of the research investigation. The research study planning and designing was done under her guidance. Author: Preeti Sharma. Contribution: The experimental research work was carried out by her. The laboratory work and compilation of research data was done by her. The author(s) read and approved the final manuscript.

\section{Funding}

The research work was carried out without support of any funding agency.

\section{Ethics approval and consent to participate}

The animal ethical approval reference no. BU/BT/402/14-15.

\section{Consent for publication}

The authors have approved and consent for publication.

\section{Competing interests}

There is no conflict of interest.
Received: 26 September 2019 Accepted: 6 April 2020

Published online: 09 July 2020

\section{References}

1. Callery MP, Kamei T, Flye MW. Kupffer cell blockade increases mortality during intra-abdominal sepsis despite improving systemic immunity. Arch Surg. 1990;125(1):36-41.

2. Rietschel ET, Holst O, Brade L, Muller-Loennies S, Mamat U, Zahringer U, et al. Bacterial endotoxin: chemical constitution, biological recognition, host response, and immunological detoxification. Curr Top Microbiol Immunol. 1996;216:39-81.

3. Berczi I, Bertok I, Bereznai T. Comparative studies on the toxicity of Escherichia coli lipopolysaccharide endotoxin in various animal species. Can J Microbiol. 1966;12(5):1070-1.

4. Park HS, Jung HY, Park EY, Kim J, Lee WJ, Bae YS. Cutting edge: direct interaction of TLR4 with NAD(P) H oxidase 4 isozyme is essential for lipopolysaccharide-induced production of reactive oxygen species and activation of NF-kappa B. J Immunol. 2004;173(6):3589-93.

5. Weiss SJ. Tissue destruction by neutrophils. N Engl J Med. 1989;320(6):36576.

6. Halliwell B. Free radicals, antioxidants, and human disease: curiosity, cause or consequence. Lancet. 1994;344:721-4.

7. Prins JM. Antibiotic induced release of endotoxin - clinical data and human studies. J Endotoxin Res. 1996;3(3):269-73.

8. Bierre AR, Koelmeyer TD. Pulmonary fat and bone marrow embolism in aircraft accident victims. Pathology. 1983;15:131-5.

9. Lee HN, Surh YJ. Therapeutic potential of resolvins in the prevention and treatment of inflammatory disorders. Biochem Pharmacol. 2012;84(10):134050.

10. Yingkun $N$, Zhenyu $W$, Jing $L$, Xiuyun $L$, Huimin $Y$. Stevioside protects LPSinduced acute lung injury in mice. Inflammation. 2013;36(1):242-50.

11. Kaur S, Anurag A, Tirkey N, Chopra K. Reversal of LPS-induced central and peripheral hyperalgesia by green tea extract. Phytother Res. 2005;19(1):3943.

12. Lee $Y$, Jung JC, Jang S, Kim J, Ali Z, Khan IA, et al. Anti-inflammatory and Neuroprotective effects of Consitituents isolated from Rhodolia rosea. Evid Based Complement altern med. 2013;2013:514049.

13. Hu Z, Ruiping D, Xiu L, Bian Z, Chaomei MA. Naoto Sato Protective effect of triterpenes of Ganoderma lucidum on lipopolysaccharide-induced inflammatory responses and acute liver injury. Cytokine. 2020;127:154917.

14. Kalwar SC, Sharma ML, Gurjar RD, Khandelwal MK, Wadhawan SK. Geomorphology and environmental sustainability. New Delhi: Concept Publishing Company; 2005.

15. Velmurugan $V$, Arunachalam G, Ravichandran V. Anthelmintic potential of Prosopis cineraria (Linn.) druce stem barks. Asian J Plant Sci Res. 2011;1(2): 88-91.

16. Kirtikar KR, Basu BD. Indian medicinal plants. Dehradun: International Book Distributors; 1984. p. 2

17. Velioglu YS, Mazza G, Gao L, Oomah BD. Antioxidant activity and Total Phenolics in selected fruits, vegetables and grain products. J Agric Food Chem. 1998:46:4113-7.

18. Green LC, Wagner DA, Glogowski J, Skipper PL, Wishnok JS, Tannenbaum SR. Analysis of nitrate, nitrite, and $\left({ }^{15} \mathrm{~N}\right)$ nitrate in biological fluids. Anal Biochem. 1982;126:131-8.

19. Anapach FB. Endotoxin removal by affinity sorbents. J Biochem Biophys Methods. 2001;49:665-81.

20. Erridge C, Bennett-Guerrero E, Poxton IR. Structure and function of lipopolysaccharides. Microbes Infect. 2002;4(8):837-51.

21. Ogikubo Y, Norimatsu M, Noda K, Takahashi J, Inotsume M, Tsuchiya M, Tamura $Y$. Evaluation of the bacterial endotoxin test for quantification of endotoxin contamination of porcine vaccines. Biologicals. 2004;32(2):88-93.

22. Rovin BH, Dickerson JA, Tan LC, Hebert CA. Activation of nuclear factor B correlates with MCP-1 expression by human mesangial cells. Kidney Int. 1995;48(4):1263-71.

23. Beutler B, Rietschel ET. Innate immune sensing and its roots: the story of endotoxin. Nat Rev Immunol. 2003;3(2):169-76.

24. Sepsis \& Endotoxin: Endotoxin is a potent trigger of the sepsis cascade. Available from- http://www.spectraldx.com/sepsis.html. Accessed 4 June 2019.

25. Glauser M, Zanetti G, Baumgartner JD, Cohen J. Septic shock: pathogenesis. Lancet. 1991;338:732-6. 
26. Remick D. Applied molecular biology of sepsis. J Crit Care. 1995;10(4):198212.

27. Ulevitch R, Tobias P. Receptor-dependent mechanisms of cell stimulation by bacterial endotoxin. Ann Rev Immonol. 1995:13:437-57.

28. Han YJ, Kwon YG, Chung HT, Lee SK, Simmons RL, Billiar TR, et al. Antioxidant enzymes suppress nitric oxide production through the inhibition of NF-kappa B activation: role of $\mathrm{H}$ (2) O (2) and nitric oxide in inducible nitric oxide synthase expression in macrophages. Nitric Oxide. 2001;5(5):504-13.

29. Choi YY, Kim MH, Hong J, Kim SH, Yang WM. Dried ginger (Zingiber officinalis) inhibits inflammation in a lipopolysaccharide-induced mouse model. Evid-Based Complement Altern Med. 2013;2013:914563.

30. Sandoval R, Lazcano P, Ferrari F, Pinto-Pardo N, González-Billault C, Utreras E. TNF-a increases production of reactive oxygen species through Cdk5 activation in nociceptive neurons. Front Physiol. 2018:9:65.

31. Dokka S, Shi X, Leonard S, Wang L, Castranova V, Rojanasakul Y. Interleukin10-mediated inhibition of free radical generation in macrophages. Am J Physiol Lung Cell Mol Physiol. 2001;280(6):1196-202.

32. Stanikunaite R, Khan SI, Trappe JM, Ross SA. Cyclooxygenase-2 inhibitory and antioxidant compounds from the truffle Elaphomyces granulatus. Phytother Res. 2009;23(4):575-8.

33. Thiemermann C, Vane J. Inhibition of nitric oxide synthesis reduces the hypotension induced by bacterial lipopolysaccharides in the rat in vivo. Eur J Pharmacol. 1990;182(3):591-5.

\section{Publisher's Note}

Springer Nature remains neutral with regard to jurisdictional claims in published maps and institutional affiliations.

\section{Submit your manuscript to a SpringerOpen ${ }^{\circ}$ journal and benefit from:}

- Convenient online submission

- Rigorous peer review

- Open access: articles freely available online

High visibility within the field

- Retaining the copyright to your article 